\title{
Galectin-3 immunostaining in thyroid neoplasms
}

\author{
Imunomarcação por galectina-3 em neoplasias de tireóide
}

Marcos Emanuel de Alcântara Segura', Albino Verçosa de Magalhães ${ }^{2}$

\begin{abstract}
key words
abstract

Galectin-3

Thyroid

Although fine-needle aspiration biopsy (FNAB) of the thyroid gland is the most important presurgical proceeding in defining the malignancy of a nodular lesion, it has limitations such as shared cytological morphology between malignant and benign lesions. Galectin-3, a ß-galactoside-binding lectin is expres-

Papillary carcinoma sed mainly by malignant thyroid neoplasms. Fifty-seven specimens, including 14 papillary carcinomas,

Follicular carcinoma 22 follicular carcinomas and 21 follicular adenomas were tested for immunohistochemical staining against galectin-3. Normal thyroid adjacent to neoplastic tissue was also examined in 48 cases. All

Follicular adenoma cases of papillary carcinoma were cytoplasmic stained, 18 cases of follicular carcinoma were cytoplasmic stained, and one case of follicular adenoma showed nuclear staining. No case of normal thyroid showed immunoreactivity. Sensitivity, specificity, positive predictive value and negative predictive value were respective $88 \%, 98 \%, 96 \%$, and $94 \%$. Galectin- 3 expression is a valuable evidence of malignancy in cases where cytomorphological features are not conclusive. This immunomediated method could increase diagnosis accuracy for $F N A B$, thus making surgery indication more precise.
\end{abstract}

resumo

A punção aspirativa por agulha fina de tireóide é o método pré-cirúrgico mais importante na definição da malignidade de uma lesão nodular. Entretanto esse procedimento apresenta limitações, como características morfológicas comuns entre neoplasias malignas e benignas. A expressão de uma lectina ligante de ß-galactosídeos chamada galectina-3, aumentada em neoplasias malignas de tireóide, poderia ser utilizada como marcador de malignidade para neoplasias de tireóide. Cinqüenta e sete casos, entre eles 14 carcinomas papilares, 22 carcinomas foliculares e 21 adenomas foliculares, foram estudados quanto à expressão da galectina-3 por métodos imuno-histoquímicos. O tecido tireoidiano normal, adjacente ao tecido neoplásico, também foi avaliado em 48 casos. Todos os casos de carcinoma papilar e 18 casos de carcinoma folicular apresentaram marcação citoplasmática; um caso de adenoma folicular apresentou marcação nuclear. Nenhum caso de tecido tireoidiano normal demonstrou imunomarcação. Sensibilidade, especificidade, valor preditivo positivo e negativo foram respectivamente $88 \%, 98 \%$, 96\% e 94\%. A expressão da galectina-3 é uma evidência valiosa de malignidade nos casos em que as características citomorfológicas não forem conclusivas. A marcação por imunocitoquímica poderá aumentar a exatidão diagnóstica nos exames citológicos por aspiração de tireóide, tornando a indicação cirúrgica mais precisa. unitermos

Galectina-3

Imuno-histoquimica

Tireóide

Carcinoma papilar

Carcinoma folicular

Adenoma folicular

\footnotetext{
1. Medical doctor; resident on Pathology, Hospital de Base do Distrito Federal (HBDF).

2. Chairman professor of Pathology, PhD in Pathology, Department of Pathology, Universidade de Brasilia (UnB).

Work developed at the Laboratory of Pathology, Faculty of Medicine, Universidade de Braślia, and supported by Conselho Nacional de Desenvolvimento Cientifico e Tecnológico (CNPq), Fundação de Empreendimentos Cientificos e Tecnológicos (FINATEC) and Programa Institucional de Bolsas de Iniciação Científica (PIBIC/UnB).
} 


\section{Introduction}

Thyroid carcinoma is the most frequent endocrine malignancy. Fine-needle aspiration biopsy (FNAB), scintigraphy, and ultrasonography are procedures currently used on investigation of a nodular lesion. FNAB is the most important method in defining the malignancy of a neoplasm. It shows great diagnostic accuracy for medullary and anaplastic carcinomas, but for papillary carcinoma (the most common) false-negative results are not $\operatorname{rare}^{(13,23)}$. Nevertheless the FNAB procedure has limitations such as inadequate sampling and shared cytological morphology between malignant and benign lesions $\mathbf{s}^{(5,14,23)}$. Morphological distinction between hyperplastic adenomatous nodules, well-differentiated follicular carcinomas, and follicular variants of papillary carcinoma is difficult ${ }^{(2,4)}$.

Criteria for follicular carcinoma diagnosis are based on demonstration of vascular and capsular invasion ${ }^{(11)}$. These criteria can only be fulfilled in histological sections, performed after thyroidectomy. Therefore, on presurgical period, distinction between malignant and benign disease is not accurate using current available methods. This background is responsible for only $10 \%$ of resected glands being classified as malignant ${ }^{(15)}$. Patients with inconclusive cytological diagnosis are referred to surgery, and definitive diagnosis is given using the excised gland. This approach has great economical and psychological impact for the patient as well as for the health care providers. The magnitude of this problem may be realized by noting that $4 \%$ of Americans between 30 and 60 years have palpable thyroid nodules ${ }^{(28)}$.

As a result of the previous considerations, a presurgical marker for thyroid malignancy would be extremely useful for rational decision on clinical observation or surgical intervention, avoiding refer patients with benign lesions to surgery. Galectin-3, a ß-galactoside-binding lectin, has been involved in various physiologic and pathologic functions, such as cell growth, cellular adhesion, inflammation, apoptosis, and neoplastic transformation $(1,12,17,19,21,24,27,33)$. Xu et al. showed that galectin-3 is over-expressed in follicular and papillary carcinomas of thyroid, but not expressed in non-malignant lesions ${ }^{(32)}$. These findings were corroborated by other authors ${ }^{(3,8,10,18,25)}$. In fact, Bartolazzi et al. ${ }^{(3)}$ have conducted a prospective multicentre study that showed 99\% accuracy in differentiating benign and malignant lesions, using immunodetection of galectin-3. Following stu$\operatorname{dies}^{(6,9,20)}$, however, did not show strong relation between thyroid malignancy and galectin- 3 expression. Before the application of this method on clinical practice, several trials on the expression of galectin-3, in histological and cytological samples, should be taken in order to know the sensitivity and specificity of the method in detecting malignant neoplasms. The objective of the present experiment is to describe the prevalence of galectin-3 expression on thyroid neoplasms, and to assay sensitivity and specificity of galectin-3 as a marker for malignant thyroid neoplasms.

\section{Materials and methods}

\section{Tissue specimens}

Cases were retrieved from the archives of the Departments of Anatomical Pathology of both Hospital Universitário de Brasília (HUB) and Hospital de Base do Distrito Federal (HBDF). Specimens had been routinely fixed in formalin and processed after paraffin embedding. Fifty-seven samples, including 14 papillary carcinomas, 22 follicular carcinomas and 21 follicular adenomas, obtained by thyreoidectomy from 1992 to 2000 were selected for analysis. Normal thyroid adjacent to neoplastic tissue was also examined in 48 cases.

\section{Immunohistochemistry}

The immunohistochemical procedure followed the method described by Hsu et al. ${ }^{(16)}$. Briefly, representative sections of $4 \mu \mathrm{m}$ obtained from paraffin blocks were deparaffinized and rehydrated. Endogenous peroxidase was quenched with $3 \% \mathrm{H} 2 \mathrm{O} 2$ diluted in methanol. Sections were incubated overnight in humid chamber with mouse monoclonal antibody anti-galectin-3, clone $9 \mathrm{C} 4$ (Novocastra Laboratories, UK) at $4^{\circ} \mathrm{C}$. The dilution used was 1:500. Sections were then incubated with biotinylated secondary antibody (DAKO, USA) for 30 minutes at room temperature. Indirect immunoperoxidase was carried out using a commercially available avidin-biotin staining kit (DAKO, USA). The immunoenzimatic activity was developed with 3,3'-diaminobenzidine tetrahydrochloride (DAB) solution. Haematoxylin was used for counterstaining.

Grading of stain was established as follows: (0) no positive cells; $(+)$ less than $10 \%$ of positive cells; $(++) 11 \%-25 \%$ of positive cells; $(+++) 26 \%-50 \%$ of positive cells; $(++++)$ more than $50 \%$ of positive cells.

\section{Statistical analysis}

Sensitivity, specificity, positive and negative predictive values for the immunostaining method were assessed taking histomorphological diagnosis as gold standard. Sensitivity 
was defined as the ratio between the number of carcinomas with positive results and the total number of thyroid cancers. Specificity was defined as the ratio between the number of benign and normal thyroid tissues with negative results and the total number of non-malignant tissues. Positive and negative predictive values were respectively calculated as follows: number of carcinomas with positive results divided by the total number of cases with positive results, and the number of benign and normal tissues divided by the total number of cases with negative results. All data were expressed in percentage.

\section{Results}

Table 1 summarizes the immunohistochemical reaction of galectin-3 in the cases studied.

Expression of galectin-3 in papillary carcinoma - All cases of papillary carcinoma showed strong (++++) or intermediate (++) immunoreaction against galectin-3. Strong cytoplasmic staining was observed in all cases and rare nuclear localization was also observed (Figure 1).

Expression of galectin-3 in follicular carcinoma - Eighteen of 22 follicular carcinomas expressed galectin-3 diffusely. Cytoplasmic localization was dominant with frequent luminal surface staining (Figure 2).

Expression of galectin-3 in follicular adenoma - Twenty cases of adenomas did not express galectin-3. Only one in 21 cases had a focal (+) immunostaining. This immunoreactive case (Figure 3), from a 40-year-old female, showed predominant nuclear expression of galectin-3. Colloid was immunostained in focal areas where follicular cells were positive. Haematoxylin-eosin preparations were revised and no vascular or capsular invasion was detected in this case.

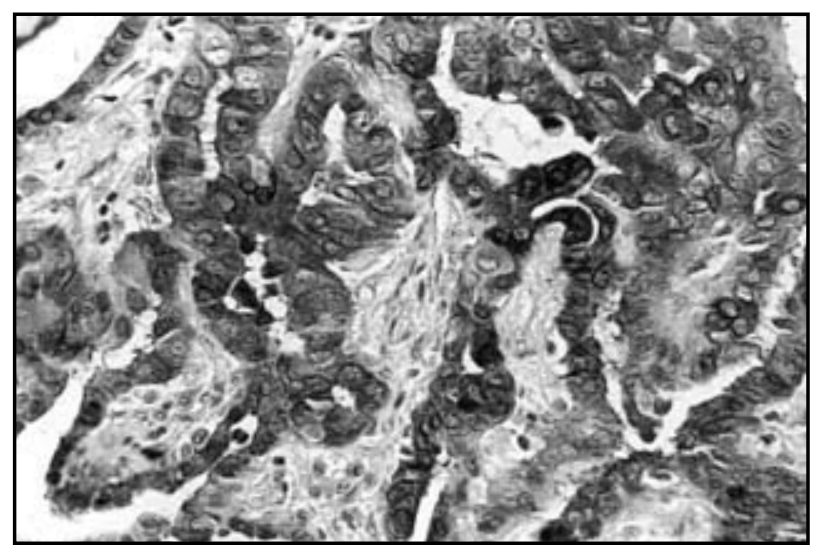

Figure 1 - Papillary carcinoma. Strong cytoplasmic galectin-3 immunostaining. Avidin-biotin immunoperoxidase with hematoxylin counterstain. Magnification x 400

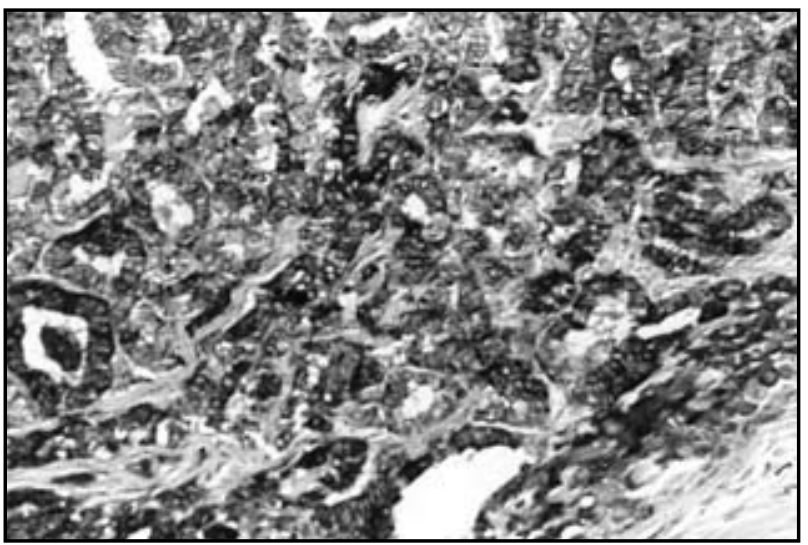

Figure 2 - Follicular carcinoma. Dominant cytoplasmic galectin-3 immunostaining with frequent luminal surface staining. Avidin-biotin immunoperoxidase with hematoxylin counterstain. Magnification x 400

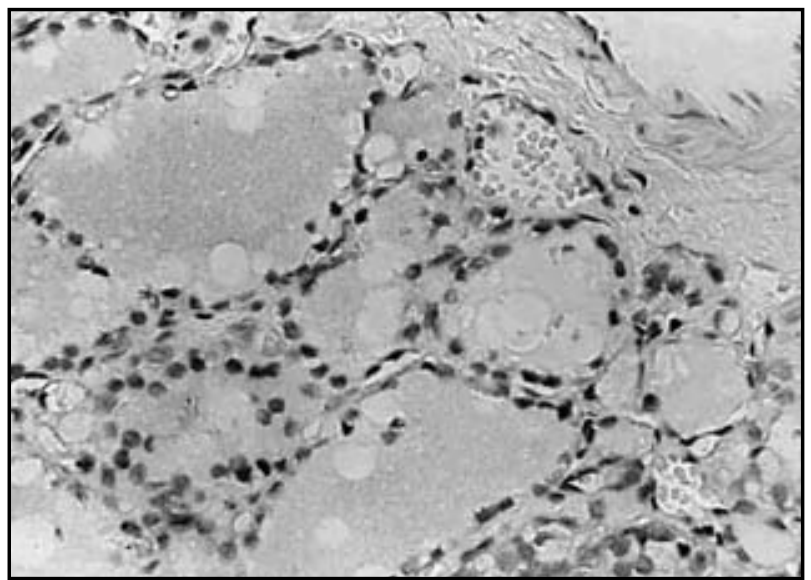

Figure 3 - Follicular adenoma from a 40-year-old female that showed positive galectin-3 immunostaining. Note predominant nuclear expression and colloid immunostaining. Avidin-biotin immunoperoxidase with hematoxylin counterstain. Magnification $\times 400$

Expression of galectin-3 in normal thyroid - Among 57 cases studied, 48 had adequate sampling of normal thyroid tissue for analysis. No expression was observed in normal tissue.

Expression of galectin-3 by stromal cells - Some stromal cells, such as nerve fibers, fibroblast, smooth muscle, inflammatory cells, and endothelial cells showed scattered immunoreaction.

Statistical analysis - Data showed sensitivity of $88 \%$, specificity of $98 \%$, positive predictive value of $96 \%$ and negative predictive value of $94 \%$ (Table 2).

\section{Discussion}

Current presurgical methods are not able to differentiate follicular adenoma from follicular carcinoma. No clinical, ecographic or scintigraphic features are reliable 


\section{Table 1 Immunohistochemical expression of galectin-3 according to histological classification}

\begin{tabular}{cccccccc}
\hline & \multicolumn{7}{c}{ Positivity } \\
Histological diagnosis & Total & Negative & + & ++ & +++ & +++ & Positive (\%) \\
\hline Papillary carcinoma & 14 & 0 & 0 & 1 & 0 & 13 & 100 \\
Follicular carcinoma & 22 & 4 & 0 & 2 & 4 & 12 & 81 \\
Follicular adenoma & 21 & 20 & 1 & 0 & 0 & 0 & 4,7 \\
Normal thyroid & 48 & 48 & 0 & 0 & 0 & 0 & 0 \\
\hline
\end{tabular}

\begin{tabular}{cc|} 
Table 2 & \multicolumn{2}{c}{$\begin{array}{l}\text { Statistical evaluation of galectin-3 } \\
\text { expression }\end{array}$} \\
\hline Variable & Percentage (\%) \\
\hline Sensitivity & 88 \\
Specificity & 98 \\
Positive predictive value & 96 \\
Negative predictive value & 94 \\
\hline
\end{tabular}

for labeling a follicular lesion as malignant or benign ${ }^{(29,31)}$. Although FNAB report is the most important indication for surgery, this procedure has limitations with sampling and overlapping morphological features between benign and malignant neoplasms. An FNAB report as suspect follicular nodule refers a patient to surgery, but many patients in this case will have benign diseases on paraffin preparations. A rational presurgical evaluation of these nodules would prevent surgical risk, lifetime hormone reposition and hospital cost.

In this histological study galectin-3 was specifically expressed by malignant neoplasm, showing that this molecule could be used as an adequate marker for malignant follicular cells. Our data corroborate previous works $(4,8,10,18,25,32)$ that found consistent expression of galectin-3 by papillary carcinomas, some negative results for follicular carcinomas, and erratic expression by adenomas. High percentages for sensitivity, specificity and predictive values, obtained by our study suggest that galectin- 3 expression by a follicular cell may be used as marker for its malignancy.

Adenomas expressing galectin-3, as described above, have been classified by previous works as carcinomas without morphological evidence of capsular and vascular invasion $^{(4,7,8,25)}$. Thus, a new possibility of detecting early thyroid cancer can be accomplished with galectin-3 immunostaining test. However more investigation is certainly needed to certify if this finding is a true or a false positive result.

Cytoplasmic galectin-3 expression was found only in carcinomas, and therefore it may be considered an evidence of malignancy. Nuclear staining was not consistently associated with malignant neoplasm and should not be a marker for cancer, until more data are available. Cytoplasmic predominance expression of galectin-3 has been related to progression of normal tissue to adenoma and carcinoma in the colon carcinoma model(22). Our data and previous studies suggest that the same pattern of cellular staining can be used with thyroid neoplasm.

Galectin-3 may play an important role in malignant transformation, especially in cell adherence and metastasis. Several works have associated this molecule with metastasis capability $^{(26,27)}$ and malignant transformation ${ }^{(30,34)}$.

Our work supports previous findings that this immunodiagnostic method is a simple, cheap and important diagnostic support in distinguishing malignant and benign thyroid neoplasm. Before application of this method on cytological samples, histological data should be gathered for knowledge of diagnosis statistics.

The immunocytochemical method is preferred to other molecular biology-based methods. Because of constitutional stromal expression of galectin-3, methods like immunoblotting show false-positive results ${ }^{(32)}$. Morphological evaluation associated with immunocytostaining with galectin- 3 should be the best approach for presurgical evaluation for thyroid nodules.

\section{Acknowledgments}

We thank Dr. Fernando Schmitt (Instituto de Patologia e Imunologia Molecular da Universidade do Porto [IPATIMUP]) for reviewing and suggestions. We are also indebted to Dr. Luciana Naves (Universidade de Brasília) and Dr. Maria Teresa de Godoy Morais for valuable supporting. 


\section{References}

I. AKAHANI, S. et al. Galectin-3: a novel antiapoptotic molecule with functional $\mathrm{BHI}(\mathrm{NWGR})$ domain of bcl-2 family. Cancer Res, v. 57, n. 23, p. 5272-6, 1997.

2. BALOCH, Z.W. et al. Fine-needle aspiration of thyroid: an institutional experience. Thyroid, v. 8, n. 7, p. 565-9, 1998.

3. BARTOLAZZI, A. et al. Application of an immunodiagnostic method for improving preoperative diagnosis of nodular thyroid lesions. Lancet, v. 357, n. 9269, p. 1644-50, 2001.

4. BARTOLAZZI, A. Improving accuracy of cytology for nodular thyroid lesions. Lancet, v. 355, n. 9216, p. 1661-2, 2000.

5. CARAWAY, N. P.; SNEIGE, N.; SAMAAN, N. A. Diagnostic pitfalls in thyroid fine-needle aspiration: a review of 394 cases. Diagn Cytopathol, v. 9, n. 3, p. 345-50, 1993.

6. CASEY, M. B.; LOHSE, C. M.; LLOYD, R.V. Distinction between papillary thyroid hyperplasia and papillary thyroid carcinoma by immunohistochemical staining for cytokeratin 19, galectin-3, and HBME-I. Endocr Pathol, v. 14, n. I, p. 55-60, 2003.

7. COLI,A. et al. Galectin-3, a marker of well-differentiated thyroid carcinoma, is expressed in thyroid nodules with cytological atypia. Histopathology, v. 40, n. I, p. 80-7, 2002.

8. CVEJIC, D. et al. Immunohistochemical localization of galectin-3 in malignant and benign human thyroid tissue. Anticancer Res, v. 18, n. 4A, p. 2637-4I, 1998.

9. FEILCHENFELDT, J. et al. Expression of galectin-3 in normal and malignant thyroid tissue by quantitative PCR and immunohistochemistry. Mod Pathol, v. 16, n. II, p. III723, 2003.

I0. FERNANDEZ, P. L. et al. Galectin-3 and laminin expression in neoplastic and non-neoplastic thyroid tissue. J Pathol, v. ।81, n. I, p.80-6, 1997.

I I. FRANSSILA, K. O. et al. Follicular carcinoma. Semin Diag Pathol, v. 2, p. IOI-22, 1985.

12. FRIGERI, L. G.; ZUBERI, R. I.; LIU, F.T. Epsilon BP, a ß-galctosidebinding animal lectin, recognizes $\mathrm{Ig} E$ (Fc epsilon $\mathrm{RI}$ ) receptor and activates mast cells. Biochemistry, v. 32, n. 30, p. 7644-9, 1993.

13. GHARIB, H.; GOELLNER, J. R. Fine needle aspiration biopsy of the thyroid: an appraisal. Ann Intern Med, v. I I 8, p. 2829, 1993.

14. HALL, T. L. et al. Sources of diagnostic error in fine needle aspiration of the thyroid. Cancer, v. 63, n. 4, p. 718-25, 1989.

15. HEDINGER, C. E. Problems in the classification of thyroid tumors. Their significance for prognosis and therapy. Schweiz Med Wochenschr, v. I23, n. 36, p. I673-8I, 1993.

16. HSU, S. M.; RAINE, L.; FRANGER, H. Use of avidinbiotin-peroxidase complex $(A B C)$ in imunoperoxidase techniques: a comparison between $A B C$ and unlabeled antibody (PAP) procedure.J Histochem Cytochem, v. 29, n. 4, p. 577-80, 1981.

17. INOHARA, H. et al. Interactions between galactin-3 and Mac- 2-binding protein mediate cell-cell adhesion. Cancer Res, v. 56, n. 19, p. 4530-4, 1996.

18. INOHARA, $H$. et al. Expression of galectin-3 in fine-needle aspirates as a diagnostic marker differentiating benign from malignant thyroid neoplasms. Cancer, v. 85, n. II, p. 2475-84, 1999.

19. INOHARA, H.; RAZ, A. Functional evidence that cell surface galactin-3 mediates homotypic cell adhesion. Cancer Res, v. 55, n. 15, p. 3267-7I, 1995.

20.JAKUBIAK-WIELGANOWICZ, M. et al. Usefulness of galectin3 immunohistochemistry in differential diagnosis between thyroid follicular carcinoma and follicular adenoma. Pol J Pathol, v. 54, n. 2, p. I I - -5, 2003.

21. LIU, F.T. S-type mammalian lectins in allergic inflammation. Immunol Today, v. I4, n. 10, p. 486-90, 1993.

22. LOTZ, M. M. et al. Decreased expression of Mac-2 (carbohydrate binding protein 35) and loss of its nuclear localization are associated with the neoplastic progression of colon carcinoma. Proc Natl Acad Sci USA, v. 90, n. 8, p. 3466-70, 1993.

23. McHENRY, C. R. et al. Influence of fine needle aspiration biopsy and frozen section examination on the management of thyroid cancer. Am J Surg, v. 166, p. 353-6, 1993.

24. MOUTSATSOS, I. K. et al. Endogenous lectins from cultured cells: nuclear localization of carbohydrate-binding protein 35 in proliferating 3 T3 fibroblast. Proc Natl Acad Sci USA, v. 84, n. 18, p. 6452-6, 1987.

25. ORLANDI, F. et al. Galectin-3 is a presurgical marker of human thyroid carcinoma. Cancer Res, v. 58, n. I4, p. 3015 20, 1998.

26. RAZ, A.; LOTAN, R. Endogenous galactoside-binding lectins: a new class of functional tumor cell surface molecules related to metastasis. Cancer Metastasis Rev, v. 6, n. 3, p. 433-52, 1987.

27. RAZ, A. et al. Evidence for the role of $34 \mathrm{kDa}$ galactosidebinding lectin in transformation and metastasis. Int J Cancer, v. 46, n. 5, p. 87I-7, 1990.

28. ROSAI, J.; CARCANGIU, M. L.; De LELLIS, R. A. Atlas of tumor pathology: tumours of the thyroid gland. 3rd series, fascicle 5. Washington DC: Armed Force Institute of Pathology, 1992. p. 343.

29. SCHLINKERT, R.T. et al. Factors that predict malignant thyroid lesions when fine-needle aspiration is "suspicious for follicular neoplasm”. Mayo Clin Proc, v. 72, n. 10, p. 913-6, 1997.

30. TAKENAKA, Y. et al. Malignant transformation of thyroid follicular cells by galectin-3. Cancer Lett, v. 195, n. I, p. III-9, 2003.

3I. TUTTLE, R. M.; LEMAR, H.; BURCH, H. B. Clinical features associated with an increased risk of thyroid malignancy in patients with follicular neoplasia by fine-needle aspiration. Thyroid, v. 8, n. 5, p. 377-83, 1998. 
32. XU, X. C.; EI-NAGGAR,A. K.; LOTAN, R. Differential expression of galectin-I and galectin-3 in thyroid tumors. Potential diagnostic implications. Am J Pathol, v. I47, n. 3, p. 8I 5-22, 1995.

33. YANG, R. Y.; HSU, D. K.; LIU, F. T. Expression of galectin-3 modulates T-cell growth and apoptosis. Proc Natl Acad Sci USA, v. 93, n. 13, p. 6737-42, 1996.

34. YOSHII, T, et al. Galectin-3 maintains the transformed phenotype of thyroid papillary carcinoma cells. Int J Oncol, v. 18, n. 4, p. 787-92, 2001

70910-900 - Brasília-DF

Tel.: (61) 307-2178/307-2527

Fax: (61) 273-0105

e-mail: segura_m@terra.com.br 